\title{
ENDOSYMBIOTIC CHLOROPLASTS IN MOLLUSCAN CELLS CONTAIN PROTEINS SYNTHESIZED AFTER PLASTID CAPTURE
}

\author{
SIDNEY K. PIERCE ${ }^{1, *}$, RACHEL W. BIRON ${ }^{1, \dagger}$ AND MARY E. RUMPHO ${ }^{2}$ \\ ${ }^{1}$ Department of Zoology, University of Maryland, College Park, MD 20742, USA and ${ }^{2}$ Department of Horticultural \\ Sciences, Texas A \& M University, College Station, TX 77843, USA
}

Accepted 11 July 1996

\begin{abstract}
Summary
Endosymbiotic chloroplasts within the cells of the ascoglossan slug Elysia chlorotica synthesize a variety of proteins including the large subunit of ribulose-1,5bisphosphate-carboxylase oxygenase (RuBisCO) and the

and subsequently translocated into the chloroplasts. Thus, the plastids not only synthesize proteins during this longlived association, but the host cell seems to play a role in plastid protein turnover.
\end{abstract} photosystem II protein D1. In addition, the effects of protein synthesis inhibitors suggest that some chloroplastassociated proteins are synthesized in the animal cytosol

Key words: endosymbiosis, chloroplast, slug, Elysia chlorotica, protein synthesis.

\section{Introduction}

Most plant-animal symbioses are cellular associations, with either entire algal cells residing between animal cells (Muscatine et al. 1975; Trench, 1979; Pardy et al. 1983) or a complete plant cell existing within a vacuole produced by the animal cell (Muscatine et al. 1975; Anderson, 1983). However, in the marine ascoglossan slug Elysia chlorotica, a single organelle, the chloroplast from the filamentous marine alga Vaucheria litorea, subsists within the animal cell cytosol in the complete absence of the rest of the plant cell (Graves et al. 1979; West, 1979). The slug has earned the nickname 'leaves that crawl' (Trench, 1975) because, when unfurled and crawling along the sandy bottoms of tidal marshes, the slug, which is a deep shade of green owing to the high density of chloroplasts within its tissues, bears a close resemblance to a small green leaf. As a result of this remarkable symbiosis, $E$. chlorotica survives starvation conditions in the laboratory for as long as 9 months when provided with adequate light for photosynthesis, continuing to display a net positive incorporation of carbon from photoautotrophic $\mathrm{CO}_{2}$ fixation (West, 1979; S. K. Pierce, unpublished observations).

The E. chlorotica/V. litorea symbiosis is not inherited, but must be re-established with each generation of slugs (West, 1979; Trench, 1975; Taylor, 1970). Adult E. chlorotica feed only upon two species of alga, $V$. litorea and $V$. compacta (West, 1979). At metamorphosis from planktotrophic veliger to its adult form, E. chlorotica forms an intracellular symbiotic association with chloroplasts from $V$. litorea. After juvenile slugs have ingested the contents of $V$. litorea filaments, specific cells lining the tubules of the extensive digestive system selectively take up and retain the algal chloroplasts (West, 1979). The long-term survival of the chloroplasts within the animal cells suggests that these plastids possess an extremely high degree of genetic and biochemical autonomy, or that the host cells of $E$. chlorotica play a significant role in promoting the survival of the chloroplasts, or perhaps both.

Although associations of this type occur in other ascoglossan species (Taylor, 1970; Greene, 1970), including the closely related European ascoglossan Elysia viridis, which forms a symbiosis with chloroplasts from the alga Codium fragile (Trench, 1975), none is capable of maintaining the endosymbiotic chloroplasts for as long as E. chlorotica. The longevity of the E. chlorotica/V. litorea symbiosis suggested that a study of this relationship might provide information about the degree of genetic autonomy of the endosymbiotic chloroplasts as well as the contribution that the slug cells may be making to the longevity of the chloroplasts.

The ability of the plant organelle to survive within an animal cytoplasm suggests that more fundamental biochemical interactions exist between the cell and the foreign organelle than would occur in an extracellular symbiosis. In plant cells, chloroplast function requires both the integration of two separate and distinct genomes, that of the plant nucleus and that of the chloroplast itself (Kowallik, 1989; Berry-Lowe and Schmidt, 1991; Gounaris et al. 1986), and a coordinated transduction of light signals between the cytosol and the chloroplast (Mullet, 1993). Several of the chloroplast proteins necessary for continued photosynthesis, including several that suffer photo-oxidative damage during the light reactions of

*e-mail: pierce@zool.umd.edu.

†Present address: Department of Biology, Dartmouth College, Hanover, NH 03784, USA. 
photosynthesis, must be continuously replaced (Schuster $e$ t al. 1988; Orwitz, 1990) and are encoded by the plant nuclear genome (Keegstra, 1989; Soll and Alefsen, 1993). The chloroplast genome itself also encodes several light-labile proteins required for photosynthesis (Greenburg et al. 1989; Mattoo et al. 1989; Barber and Anderson, 1992). In addition, the synthesis, maintenance and degradation of some of these chloroplast proteins are often light-sensitive, mediated through cytosolic photoreceptors (Gamble and Mullet, 1989a,b; Christopher and Mullet, 1994). Thus, the persistence of photosynthetic function of the $V$. litorea chloroplasts within $E$. chlorotica cells suggests the existence of a mechanism for either long-term maintenance or de novo synthesis of these proteins in the absence of both the plant nucleus and cytoplasm. Unless some unidentified mechanism exists within the $V$. litorea chloroplast to repair the damage that occurs during light exposure, those proteins that are usually encoded by the plant nuclear genome and targeted to the plastid must be synthesized for the endosymbiotic chloroplasts, either on the plastid ribosomes or on the animal cytosolic ribosomes. In addition, the regulatory signals that normally originate from the plant cytosolic photoreceptors must be entirely absent, somehow taken over by the symbiotic plastid, or somehow accomplished in the molluscan cytosol.

Although some earlier attempts were made to determine the biochemical interactions between the cells of $E$. viridis and its endosymbiotic chloroplasts, very little is known about protein synthesis and turnover within the endosymbiotic chloroplasts. Autoradiography of thin sections of ${ }^{3} \mathrm{H}$-leucine labeled $E$. viridis indicated small amounts of radioactivity over a small proportion of the chloroplasts, and specific tests for the large subunit of ribulose-1,5-bisphosphate-carboxylase oxygenase (RuBisCO) failed to demonstrate any synthesis (Trench, 1975). Additional research on the synthesis of other chloroplast proteins within E. viridis has not been forthcoming, perhaps stymied by the insurmountable technical difficulty of producing an isolated chloroplast fraction from the huge amount of mucus produced by the slugs (Trench et al. 1973). Thus, until now, almost no information is available on the nature of the biochemical mechanisms that permit the sustenance and maintenance of the plant organelle in the foreign environment of the molluscan cytoplasm.

We have recently developed a protocol that produces a fraction containing endosymbiotic $V$. litorea chloroplasts isolated from the rest of E. chlorotica, which has permitted us to study the synthesis of chloroplast proteins within the slug cells. Our results show that several chloroplast proteins are synthesized while the chloroplasts are residing within the molluscan cytoplasm. Furthermore, some of these proteins are synthesized in the presence of chloramphenicol, an inhibitor of plastid-directed protein synthesis.

\section{Materials and methods}

Animals and algae

Elysia chlorotica (Gould) were collected from an intertidal marsh near Menemsha Pond on Martha's Vineyard Island, Massachusetts, USA. The animals were maintained in 18.9 or 37.81 aquaria at $10^{\circ} \mathrm{C}$ in aerated artificial sea water (ASW) (Instant Ocean, 925 mosmol kg-1) on a $16 \mathrm{~h}: 8 \mathrm{~h}$ light:dark cycle (GE cool-white fluorescent tubes, $15 \mathrm{~W}$ ). Animals were collected either in the early spring (animals that had overwintered in the marsh) or in the autumn (progeny from the overwintered animals) (see West et al. 1984, for a description of the E. chlorotica life cycle).

Vaucheria litorea (C. Agardh) were collected from the same marsh and were maintained in sterile culture in an incubation chamber at $22^{\circ} \mathrm{C}$ in aerated enriched ASW (250 mosmol kg-1) [modified from $\mathrm{f} / 2$ medium (Bidwell and Spotte, 1985); all nutrient concentrations were reduced to $40 \%$ of the recommended concentrations, and $\mathrm{Na}_{2} \mathrm{SiO}_{3}$ was omitted], with $24 \mathrm{~h}$ illumination (GE fluorescent white tubes, $40 \mathrm{~W}$ ). The decreased osmolality and nutrient concentrations discourage the growth of marine diatoms and other contaminants, while allowing the euryhaline algae to thrive. The medium was filtersterilized through a $0.2 \mu \mathrm{m}$ mesh filter prior to use. Algal filaments collected from the field were thoroughly washed with ASW and then transferred to the sterile medium. After 2 days, dark green growing tips (1-3 cm in length) were trimmed from the algae with dissecting scissors, rinsed with sterile ASW $(250$ mosmol kg-1) and transferred to fresh medium. Every 2 days for several weeks, small $(<1 \mathrm{~cm}$ in length) growing tips were cut from the rapidly growing algae and transferred to new medium, until a clean culture was obtained. Thereafter, cultures were transferred to fresh medium every 7-10 days. New cultures were inoculated as needed by transferring tips to new medium.

\section{Slugs}

\section{Chloroplast isolation}

We discovered that a mucolytic agent, $N$-acetyl-L-cysteine (Mucomyst) (Reas, 1963; Grassi and Morandini, 1976), eliminates most of the copious mucus that may have foiled other attempts to study this symbiosis, while leaving the chloroplasts intact. The concentration of Mucomyst required to disperse mucus effectively in homogenates of slugs $\left(500 \mathrm{mmol}^{-1}\right)$ was determined in preliminary experiments by observing the disappearance of mucus strands in homogenates (viewed under a light microscope) with increasing concentrations of the mucolytic agent.

The slugs were rinsed in ASW, decapitated and the body rapidly cut into small pieces with a razor blade. The tissue pieces were homogenized in ice-cold buffer $\left(900 \mathrm{mmol}^{-1}\right.$ sorbitol, $50 \mathrm{mmol}^{-1} \mathrm{Mes}, 10 \mathrm{mmoll}^{-1}$ sodium EDTA, $0.5 \%$ bovine serum albumin, BSA, pH 5.5). The low $\mathrm{pH}$ of the buffer is necessary because Mucomyst works most effectively under acid conditions. Immediately prior to homogenization of the tissue, Mucomyst was added to the homogenization buffer to a concentration of $500 \mathrm{mmoll}^{-1}$. The tissue was homogenized using a Teflon/glass homogenizer, immediately diluted sevenfold with buffer (without Mucomyst) and filtered sequentially through six layers of cheesecloth, a layer of 
Endosymbiotic chloroplasts in molluscan cells 2325

Miracloth (Calbiochem) and then twice more through a double layer of Miracloth. The filtrate was centrifuged $(4300 \mathrm{~g}, 5 \mathrm{~min}$, $4{ }^{\circ} \mathrm{C}$ ), resuspended in buffer without Mucomyst and filtered sequentially through a double layer of Miracloth, a double $60 \mu \mathrm{m}$ mesh nylon net and a $10 \mu \mathrm{m}$ mesh net. This filtrate was recentrifuged, resuspended in 1-2 $\mathrm{ml}$ of buffer, passed through a double layer of Miracloth and a $20 \mu \mathrm{m}$ mesh net, a $10 \mu \mathrm{m}$ mesh net, and layered onto a pre-formed $25 \%$ Percoll gradient. The gradient was centrifuged for $15 \mathrm{~min}(13200 \mathrm{~g})$ in a swinging bucket rotor. The lower of two green bands (near the bottom of the gradient) contained intact chloroplasts, which were removed from the gradient using a glass Pasteur pipette, and the chloroplasts were washed twice with buffer (without BSA or Mucomyst) to remove residual Percoll and BSA. The final resuspended pellet was examined with phase-contrast microscopy. A yellow 'halo' around the green plastids indicated that they were intact after isolation (Walker et al. 1987). In preliminary experiments, the integrity of the isolated chloroplasts was also confirmed by transmission electron microscopy.

\section{Alga}

The procedure for isolating chloroplasts from the algae was modified from a pea chloroplast isolation protocol (Rumpho and Edwards, 1984). Percoll gradients (30\%) were prepared in advance and stored at $4{ }^{\circ} \mathrm{C}$ until use (within 24h). 3-4g (wet mass) of algal filaments was homogenized (Polytron, three short bursts, speed 6, or Sorvall Omni-mixer, high speed, three short bursts of $1-3 \mathrm{~s})$ in buffer $\left(300 \mathrm{mmol}^{-1}\right.$ sorbitol, $50 \mathrm{mmoll}^{-1}$ Hepes, $50 \mathrm{mmoll}^{-1} \mathrm{MgCl}_{2}, 1 \mathrm{mmoll}^{-1}$ EDTA, $0.2 \%$ BSA, pH 7.6) which had been chilled to a slush. The homogenate was filtered through a cheesecloth/cotton filter and centrifuged $\left(1478 \mathrm{~g}, 4^{\circ} \mathrm{C}, 2 \mathrm{~min}\right)$. The pellet was resuspended, washed in buffer and recentrifuged. This last pellet was resuspended in a small volume of buffer, and sequentially filtered through a double layer of $60 \mu \mathrm{m}$ mesh nylon net, a $20 \mu \mathrm{m}$ mesh net and a $10 \mu \mathrm{m}$ mesh net. The filtrate was gently layered onto the preformed Percoll gradient and centrifuged $\left(13200 \mathrm{~g}, 10 \mathrm{~min}, 4^{\circ} \mathrm{C}\right)$ in a swinging bucket rotor. The green band containing the intact chloroplasts was removed, and the plastids were washed in homogenization buffer without BSA to remove residual Percoll and BSA.

After each isolation, the chloroplasts were examined for intactness with phase-contrast microscopy as described above for the slug chloroplasts.

\section{Labeling and comparison of chloroplast proteins}

Two to four slugs or $1 \mathrm{~g}$ of algae were placed in artificial sea water (ASW) (930 mosmol kg-1 for slugs; $250 \mathrm{mosmol} \mathrm{kg}^{-1}$ for algae) in glass scintillation vials and placed under intense light (150 W, GE Cool Beam incandescent indoor flood lamp) at $20{ }^{\circ} \mathrm{C}$. $\quad\left[{ }^{35} \mathrm{~S}\right]$ methionine $\quad\left(0.7 \mathrm{MBq} \mathrm{ml}^{-1}\right) \quad\left(\mathrm{ICN}\right.$, trans $-{ }^{35} \mathrm{~S}-$ methionine) was added to each vial, and the samples were incubated for $6 \mathrm{~h}$ with gentle agitation in a rotating water bath. When inhibitors were used in the slug experiments, cycloheximide $\left(2 \mathrm{mg} \mathrm{ml}^{-1}\right)(\mathrm{CHI}$, which inhibits translation on
Table 1. Effects of protein synthesis inhibitors on the rates of incorporation of $\left[{ }^{35}\right.$ S $]$ methionine into chloroplast proteins of Elysia chlorotica

\begin{tabular}{|c|c|}
\hline Inhibitor & 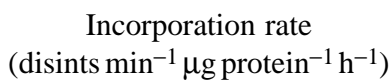 \\
\hline No inhibitor & 74 \\
\hline CAP & 61 \\
\hline CHI & 28 \\
\hline $\mathrm{CHI}+\mathrm{CAP}$ & $<8$ \\
\hline
\end{tabular}

Inhibitor concentrations used were those described in the text. CAP, chloramphenicol; CHI, cycloheximide.

$80 \mathrm{~S}$ cytosolic ribosomes) or chloramphenicol $\left(160 \mathrm{mg} \mathrm{ml}^{-1}\right)$ (CAP, which inhibits translation on $70 \mathrm{~S}$ plastid ribosomes) was added $1 \mathrm{~h}$ prior to the addition of $\left[{ }^{35} \mathrm{~S}\right]$ methionine. Effective inhibitor concentrations were determined in preliminary dose-response experiments that measured the incorporation of $\left[{ }^{35} \mathrm{~S}\right]$ methionine into trichloroacetic acid (TCA)-precipitible protein in whole slugs (Table 1). At the end of the incubation, the slugs or algae were rinsed with ASW and their chloroplasts were isolated as described above.

SDS-PAGE/autoradiography was used to compare $\left.{ }^{35} \mathrm{~S}\right]$ methionine-labeled chloroplast proteins in the slugs with those in the algae, as well as to compare the profiles of chloroplast proteins from slugs labeled in the presence or absence of the two inhibitors. Proteins from the isolated chloroplast were solubilized by boiling in SDS buffer containing $\beta$-mercaptoethanol. Samples containing equal amounts of radioactivity were loaded onto $12.5 \%$ SDS-polyacrylamide gels and separated by electrophoresis. The gels were dried and exposed to X-ray film (Kodak XOMAT-AR) at $-80^{\circ} \mathrm{C}$, for $2-30$ days depending upon the amount of radioactivity present. The molecular masses of the radiolabeled proteins were calculated by comparing their migration distances with the mobility of prestained molecular mass markers (Bethesda Research Laboratories, 14.3-200 kDa molecular mass range) run in parallel lanes.

\section{Analysis of radiolabeled chloroplast proteins}

Two criteria were used to identify the chloroplast proteins that were found to be synthesized in the above experiments. First, since photosynthesis continues for many months in the symbiotic chloroplasts, there is an obvious need for the continued production of the proteins involved in photosynthesis, especially those that are particularly labile. Second, within the above group of plastid proteins, we tested initially for those for which antibodies were available. Three proteins fit these criteria. The large subunit of the multimeric chloroplast enzyme required in carbon fixation, $\mathrm{RuBisCO}$, the $32 \mathrm{kDa}$ protein, $\mathrm{D} 1$, which is a component of the photosystem II (PSII) reaction center, and fucoxanthin chlorophyll a/c lightharvesting complex protein (FCPC). Of these three, D1, a thylakoid-membrane protein encoded by the plastid $p s b \mathrm{~A}$ gene (Gounaris et al. 1986), is light-labile with a maximum relative 
half-life of about $40 \mathrm{~h}$ in higher plants and is extremely unstable in light (Mattoo et al. 1989), making it a particularly good target for the study of chloroplast protein synthesis in $E$. chlorotica. Furthermore, the transcription of the plastid gene for D1 has recently been shown to be regulated by nuclear signals in plant cells (Christopher and Mullet, 1994). FCPC is an essential component of the PSII light-harvesting complex in diatoms and brown algae (Grossman et al. 1990) and requires constant replacement as a consequence of the photooxidative damage that occurs during photosynthesis (Orwitz, 1990).

Standard western blotting procedures were used to test for the presence of the plastid proteins in slug and algal chloroplasts (BioRad alkaline phosphatase protocol). The primary antibodies used in the blotting protocol were raised in rabbits either against D1 (from barley) (kindly provided by Dr Autar Mattoo at the USDA, Beltsville, MD, USA) or against FCPC from the chromophytic alga Pavlova gyrans (kindly provided by Dr Marvin Fawley at North Dakota State University).

Chloroplast protein $(10 \mu \mathrm{g})$ radiolabeled with $\left[{ }^{35} \mathrm{~S}\right]$ methionine as described above, either from slugs or from algae, was separated by SDS-PAGE and electrophoretically transferred to an Immobilon-P membrane (Millipore). All washes, blocking steps and antibody incubations were performed in TBST (Tris-buffered saline with Tween-20; $10 \mathrm{mmol}^{-1}$ Tris- $\mathrm{HCl}, 150 \mathrm{mmol}^{-1} \mathrm{NaCl}, 0.05 \%$ Tween 20 , $\mathrm{pH}$ 8.0) at room temperature. The membrane was blocked with $1 \%$ BSA for a minimum of $120 \mathrm{~min}$, then incubated with primary antibody for $40 \mathrm{~min}$. Following several $10 \mathrm{~min}$ washes, a $30 \mathrm{~min}$ incubation with the secondary antibody (goat antirabbit IgG whole-molecule alkaline phosphatase conjugate) and several washes with TBST, the locations of the antigens were visualized by staining the bound antibodies for alkaline phosphatase activity. Western blots were then exposed to Xray film to determine whether the immunostained proteins were also radioactively labeled.

Immunoprecipitation procedures were used to test for the presence and synthesis of D1 and the large subunit of RuBisCO. Slugs or algae were labeled with $\left[{ }^{35} \mathrm{~S}\right]$ methionine and protein extracts of the whole organism prepared as described above. These extracts were used rather than isolated chloroplasts because more radiolabeled protein was required for the immunoprecipitations than was typically available from chloroplast isolations. For each sample, 400000 disints min $^{-1}$ was incubated in immunoprecipitation buffer $\left[10 \mathrm{mmol}^{-1}\right.$ Tris-HCl, $10 \mathrm{mmol}^{-1}$ EDTA, $150 \mathrm{mmoll}^{-1} \mathrm{NaCl}, 1 \mathrm{mmol}^{-1}$ phenylmethylsulfonyl fluoride (PMSF), $1.0 \%$ Nonidet-P-40, $\mathrm{pH}$ 8.0] with a small amount of protein-A Sepharose slurry for $30 \mathrm{~min}$ on ice, with occasional inversion. The beads were removed by centrifugation and discarded. Antibody against the large subunit of RuBisCO (from Chlamydomonas sp., kindly provided by Dr Gregory Schmidt at the University of Georgia) or to D1 was then added to the sample, which was incubated overnight at $4{ }^{\circ} \mathrm{C}$ with constant mixing on a rotator $\left(1.5 \mathrm{revs} \mathrm{min}^{-1}\right)$. On the second day, protein A-Sepharose beads were added and the mixture was incubated for $3 \mathrm{~h}$ at room temperature with gentle rotation. The beads and the bound antibody-antigen complexes were removed from the solution by centrifugation $\left(12000 \mathrm{~g}, 4^{\circ} \mathrm{C}, 30 \mathrm{~s}\right)$ and washed $7-10$ times with wash buffer $\left(50 \mathrm{mmoll}^{-1}\right.$ Tris- $\mathrm{HCl}$, $5 \mathrm{mmoll}^{-1}$ EDTA, $150 \mathrm{mmoll}^{-1} \mathrm{NaCl}, 1 \mathrm{mmoll}^{-1}$ PMSF, $0.1 \%$ Nonidet-P-40). After the final wash, $40 \mu \mathrm{l}$ of SDS-PAGE electrophoresis sample buffer was added, and the sample was boiled for $4 \mathrm{~min}$. The beads were then removed by centrifugation, and the immunoprecipitated proteins contained in the supernatant were examined by SDS-PAGE/ fluorography, as described above.

\section{Results}

The profiles of chloroplast proteins from the slugs and the algae are very similar, although there is at least one polypeptide present in the slug chloroplasts that is not present in the algal chloroplasts (approximately $25 \mathrm{kDa}$ ), and a few others for which the reverse is true (Fig. 1A). In addition, the relative abundance of some proteins varies between chloroplasts isolated from the two organisms, which may suggest different rates of synthesis in the different cellular environments. Autoradiography of chloroplast proteins isolated following incubation of slugs with $\left[{ }^{35} \mathrm{~S}\right]$ methionine clearly demonstrates

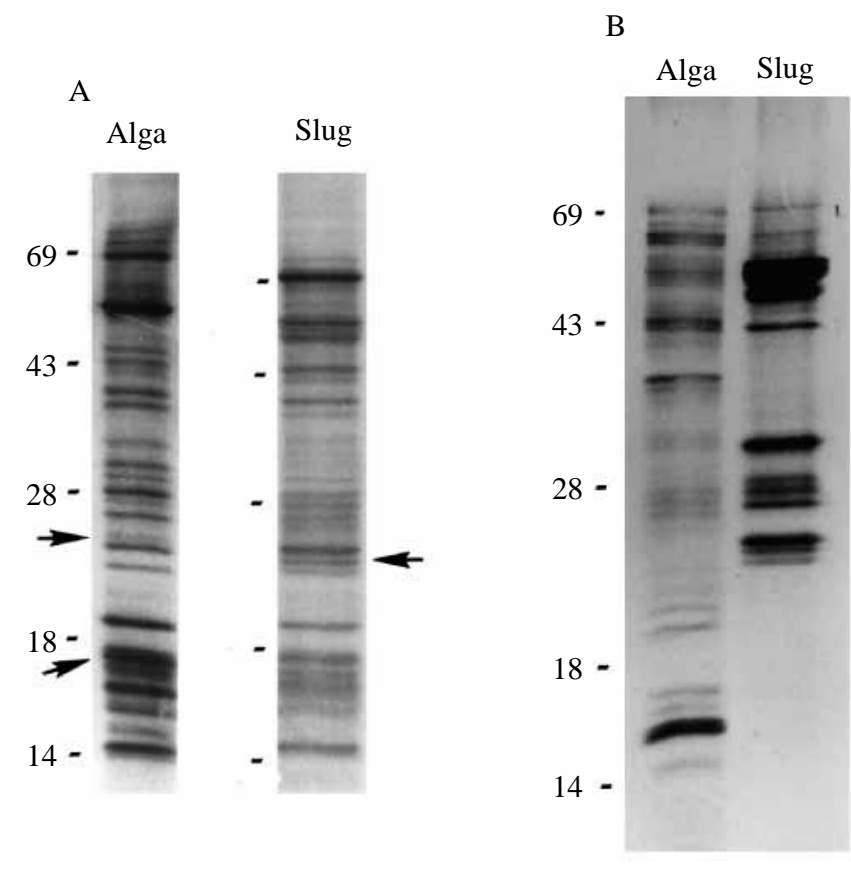

Fig. 1. (A) Protein profiles of chloroplasts isolated from Vaucheria litorea (Alga) and Elysia chlorotica (Slug) separated by SDS-PAGE and stained with Coomassie Brilliant Blue. Approximate molecular masses $(\mathrm{kDa})$ are indicated on the left. The arrows point to proteins present in either the algal or the slug plastid only. (B) Autoradiograph of gels prepared similarly to those in A showing the position of algal or slug chloroplast proteins that incorporated $\left[{ }^{35} \mathrm{~S}\right]$ methionine. Both lanes were loaded with equal amounts of TCA-precipitable radioactivity. 
that the synthesis of several chloroplast proteins occurs while the plastids are residing within the molluscan cells (Fig. 1B). This is the first conclusive evidence that chloroplast proteins are synthesized within any animal cell. Chloroplasts isolated from $V$. litorea, similarly labeled with $\left[{ }^{35} \mathrm{~S}\right]$ methionine, have a larger variety of synthesized proteins than the plastids within the slug (Fig. 1B). In the alga, most of the proteins that are visible on the stained gels also become labeled, in comparison with only approximately ten of the proteins present in chloroplasts from E. chlorotica (compare Fig. 1A and Fig. 1B). In particular, many of the lower-molecular-mass proteins (below approximately $24 \mathrm{kDa}$ ) do not incorporate radioactivity in the slug.

Both CAP and CHI inhibit the synthesis of several chloroplast proteins within the slug (Fig. 2). The action of the two inhibitors on the synthesis of chloroplast proteins in $E$. chlorotica is complementary: synthesis of chloroplast proteins that was inhibited by one drug was unaffected by the other. The syntheses of all proteins labeled in the absence of inhibitors were blocked by one or the other of the drugs, and there was no overlap between the two groups of inhibited peptides. There are two labelled bands that migrate very close to one another at approximately $56 \mathrm{kDa}$ that are not always

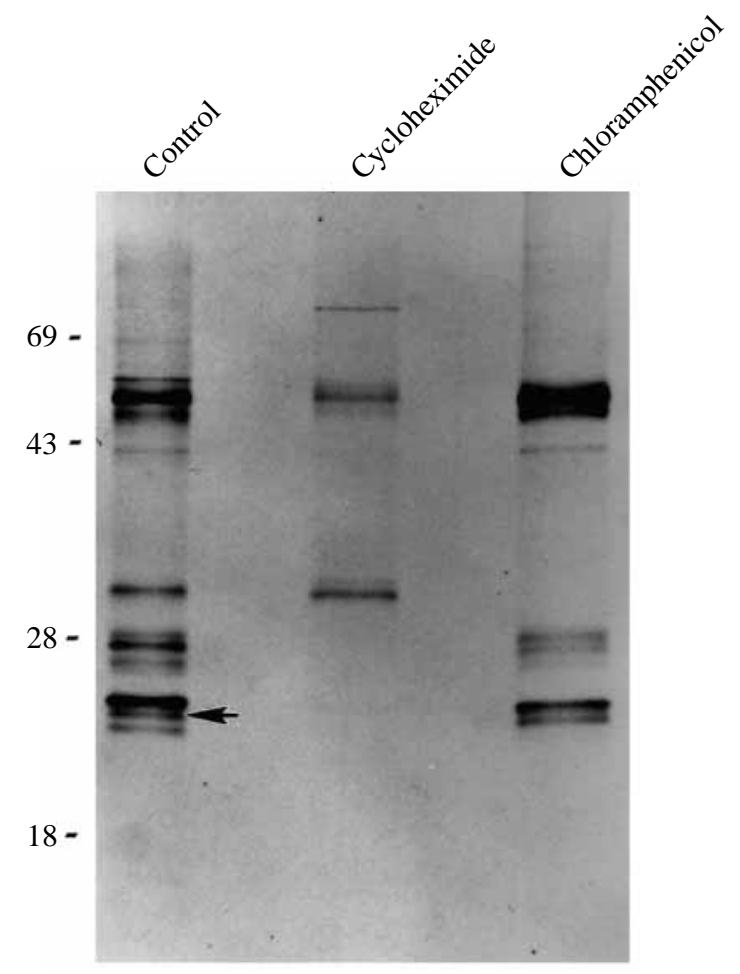

Fig. 2. Autoradiograph of an SDS-PAGE gel showing the effects of translational inhibitors on the synthesis of chloroplast proteins in Elysia chlorotica. Slugs were labeled with $\left[{ }^{35}\right.$ S $]$ methionine in the absence of any inhibitor (control) or in the presence of either cycloheximide or chloramphenicol followed by chloroplast isolation. The filled arrow indicates a protein $(25 \mathrm{kDa})$ that is not found in chloroplasts from algae and synthesis of which is inhibited by cycloheximide in the slug. Approximate molecular masses $(\mathrm{kDa})$ are indicated on the left of the gel.

resolved on every gel (Fig. 2). The synthesis of one is inhibited by CAP (and immunoprecipitates with antibody to RuBisCO; see Fig. 5 below) and that of the other is inhibited by $\mathrm{CHI}$. Almost no label becomes incorporated into chloroplast protein when the two inhibitors are used together (Table 1). In addition, synthesis of the $25 \mathrm{kDa}$ protein, which was detected only in slug chloroplasts, was inhibited by CHI (Fig. 2). Although the protein was not always visible in CoomassieBlue-stained gels of slug chloroplast proteins, it always incorporated $\left[{ }^{35} \mathrm{~S}\right]$ methionine in control and CAP-treated slugs.

We have identified one of the chloroplast proteins $(22 \mathrm{kDa})$ present in both slugs and alga as homologous with the nuclearencoded FCPC by western blotting (Fig. 3A). However, synthesis of FCPC was detected only in the algal chloroplasts (Fig. 3B).

The synthesis of a $32 \mathrm{kDa}$ protein was inhibited by CAP in slug chloroplasts (Fig. 2). Western blot (Fig. 4A) and immunoprecipitation (Fig. 4B) analyses identified this band as the thylakoid-membrane protein D1, a component of the PSII light-harvesting core complex.

Although earlier workers were not able to demonstrate RuBisCO synthesis in E. viridis chloroplasts (see above), our immunoprecipitation experiments also identified the synthesis of the large subunit of RuBisCO in E. chlorotica (Fig. 5A). This chloroplast-encoded protein incorporated radioactivity in

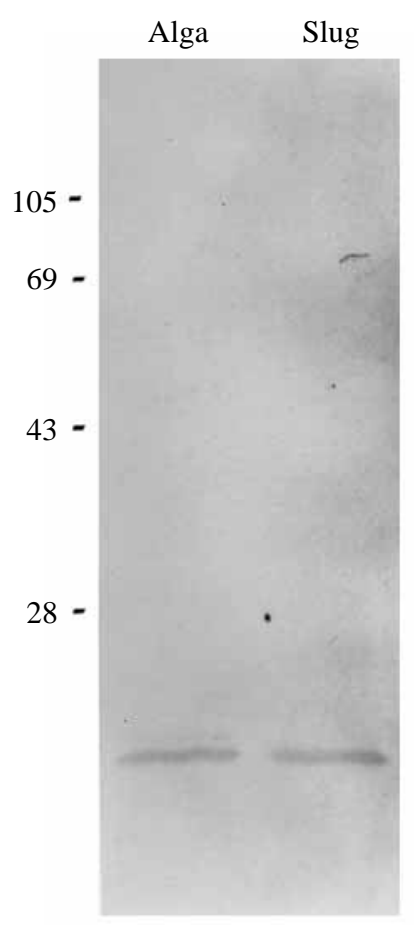

Fig. 3. (A) Western blot identification of a fucoxanthin chlorophyll a/c light-harvesting complex (FCPC) homologue in both algal and slug chloroplasts. (B) The corresponding autoradiograph showing that this protein incorporates $\left[{ }^{35} \mathrm{~S}\right]$ methionine in the alga (arrow) but not in the slug. Approximate molecular masses $(\mathrm{kDa})$ are indicated on the left of the blot. 
E. chlorotica and was identical in size $(56 \mathrm{kDa})$ to the RuBisCO large subunit protein immunoprecipitated from $V$. litorea. As expected, CAP inhibited the synthesis of the $\mathrm{RuBisCO}$ large subunit in the slug, whereas $\mathrm{CHI}$ did not (Fig. 5B).

\section{Discussion}

Our results clearly demonstrate that the relationship between $E$. chlorotica and its endosymbiotic chloroplasts is far more complex than the mere retention and exploitation of photosynthetically active chloroplasts by the slug cells. The syntheses of D1 and RuBisCO by $V$. litorea chloroplasts within E. chlorotica provide the first evidence that proteins required for photosynthesis continue to be synthesized by the endosymbiotic chloroplasts within molluscan cells. The synthesis of D1 by chloroplasts which have been separated

A

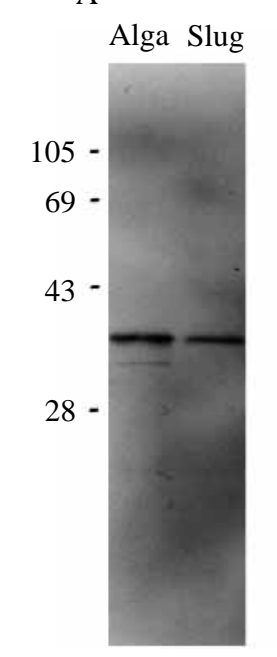

B
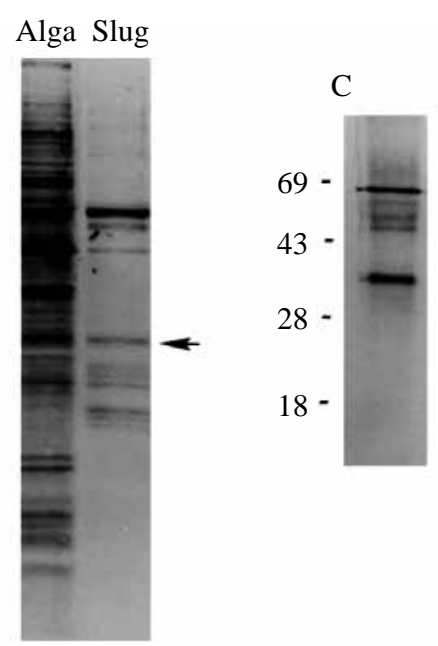

Fig. 4. Immunological identification of the thylakoid membrane protein D1. (A) Western blot demonstrating the presence of D1 in both alga and slug chloroplasts. (B) Autoradiograph of the western membrane in A showing the incorporation of label into a protein at the same location on the gel as D1 (32 kDa) (arrow). (C) Immunoprecipitation of D1 from radiolabeled slugs. from the plant nucleus and placed in a foreign cytosol is extremely interesting because the transcription and degradation of the PSII subunits have recently been shown to be differentially regulated by nuclear signals in plant cells (Gamble and Mullet, 1989a). The continued synthesis of this protein in the complete absence of signals from the plant cell may imply that significant biochemical communication occurs between the animal nucleo/cytosol and the plant organelle. However, these results need to be interpreted with caution since, in the higher plants at least, isolated chloroplasts are able to synthesize D1 (Gamble and Mullet, 1989a).

The general similarity of the total protein profiles of chloroplasts between alga and slug suggests either that most of the $V$. litorea chloroplast proteins are quite stable or that those proteins that become depleted are replaced within the slug cells. Differences in the patterns of synthesized proteins in algal and slug chloroplasts may be related to chloroplast division and development, which occur at high rates at the tips of the algal filaments (Ott and Brown, 1974), but have never been observed within the symbiotic plastids (Trench, 1975; West, 1979, as well as our own observations). Consequently, some of the chloroplast proteins that are synthesized within the alga, but not within the slug, may be long-lived structural components that do not need to be replenished for continued chloroplast function in the slug. In addition, the possibility that some of the proteins present only in the algal chloroplast preparations represent non-chloroplast protein contamination cannot be entirely excluded.

It is of great interest and potential significance that $\mathrm{CHI}$ inhibits the syntheses of several chloroplast proteins in the slug, since this suggests that the proteins are translated on cytosolic ribosomes and subsequently imported into the chloroplasts, although we cannot say for certain until the proteins have been identified. The persistence of protein synthesis in E. chlorotica, together with the change in synthesized protein profile in the presence of $\mathrm{CHI}$, demonstrates that the chloroplast translational machinery is unaffected by this inhibitor. In order for chloroplast proteins to be synthesized on ribosomes within the slug cell cytoplasm, a mechanism must exist by which the genetic information to
Fig. 5. (A) Autoradiographs of immunoprecipitated large subunit of $\mathrm{RuBisCO}$ from alga and slug chloroplasts, isolated following labeling of intact organisms with $\left[{ }^{35} \mathrm{~S}\right]$ methionine in the absence of inhibitors. (B) Similar immunoprecipitations from slug chloroplasts radiolabeled in the presence of chloramphenicol (CAP) or cycloheximide (CHI) compared with immunoprecipitations of control algae and slugs radiolabeled without either inhibitor. Approximate molecular masses are indicated on the left of each autoradiograph.

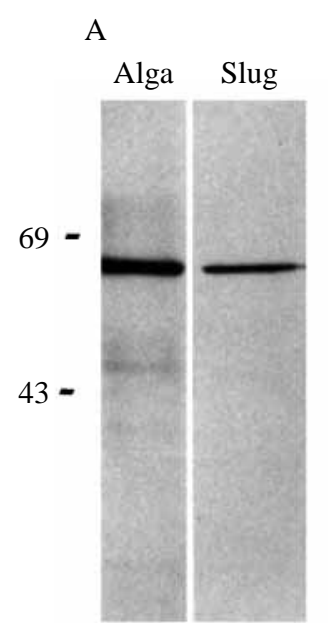


produce these proteins is, or at some point was, transmitted to the animal cell. There are three obvious possibilities how this might have occurred, all without supporting evidence at present and all of which could be investigated further within E. chlorotica. First, the slug genome may contain the genes for some components of the chloroplast, along with the necessary chloroplast-specific transit sequences, having obtained them by some earlier gene-transfer event. Although this possibility has not yet been tested in E. chlorotica, such gene-transfer events are part of the basis for the 'serial endosymbiotic theory' of evolution and are almost certain to have occurred during the initial establishment of chloroplasts and mitochondria within eukaryotic cells (Margulis and Bermudes, 1985; Khakhina, 1992; Brennicke et al. 1993). Second, the slug genome may, perhaps coincidentally, encode proteins which contain sequences that allow them entry into the chloroplast. Third, the chloroplasts may release mRNA to the cytoplasm, where it is translated into proteins which are then imported back into the chloroplast. We have begun experiments both to identify the proteins and to examine these possibilities.

All of the translational activity of $V$. litorea chloroplasts in E. chlorotica cells suggests either that the plastids possess a high degree of genetic and biochemical autonomy or that $E$. chlorotica cells contribute to chloroplast function, or perhaps both. Other species of marine slugs [Limapontia depressa (the dark form), Limapontia capitata and Alderia modesta] also harbour Vaucheria chloroplasts within the cells of their digestive diverticula, but the chloroplasts within these species retain photosynthetic function for less than 1 day after removal of the animals from the algae (Hinde and Smith, 1974). Thus, these species are not capable of sustaining chloroplast function for very long in the absence of the algal nucleus, suggesting that lengthy chloroplast survival is not solely inherent to the organelle itself. Instead, the longevity of the symbiosis between $V$. litorea chloroplasts and $E$. chlorotica suggests that the host cells of this slug play a significant role in promoting the survival of the chloroplasts. In addition, while their identity is not yet known, the possibility that chloroplast proteins are assembled within the slug cell cytoplasm, implying the movement of proteins between the cytosol and the endosymbiotic chloroplasts within the host cell, suggests that a much more complex molecular relationship may be present between $E$. chlorotica and its chloroplasts than in any other species yet described.

One of the chloroplast proteins that becomes labeled only in the algal chloroplasts, although it is present in both organisms, is FCPC. This component of the PSII light-harvesting system requires constant replacement as a consequence of photooxidative damage during photosynthesis (Orwitz, 1990). Since FCPC is nuclear-encoded (Grossman et al. 1990), it was not altogether surprising to find that it is not synthesized within the slug. However, since it is unlikely that PSII and photosynthesis can continue without an accessory light-harvesting protein, either FCPC remains functional for as long as 8 months in the slug, suggesting that it is unusually stable in $V$. litorea chloroplasts or that a different, unknown light-harvesting complex is present.
Finally, one of the proteins $(25 \mathrm{kDa})$ whose synthesis was inhibited by $\mathrm{CHI}$ and was detected only in slug chloroplasts appears to be encoded by the slug genome and translated on cytosolic ribosomes. Whether this protein is a truly unique, nuclear-encoded protein produced by the slug genome and targeted to the chloroplast remains to be determined.

This work was submitted by Rachel W. Biron to the Faculty of the Department of Zoology of the University of Maryland at College Park, MD, in partial fulfillment of the requirements of the Master of Science degree. It was supported in part by an American Chemical Society Herman Frasch Foundation Grant 343-HF92 in Agricultural Chemistry (M.E.R.), by both the Maryland and Texas Agricultural Experiment Stations, by NSF Grants IBN-9117248 (S.K.P.) and IBN-9505416 (S.K.P. and M.E.R.) and by Chesapeake Bay Funds from the Department of Zoology, University of Maryland.

\section{References}

ANDERson, O. R. (1983). The radiolarian symbiosis. In Algal Symbiosis: A Continuum of Interaction Strategies (ed. L. J. Goff), pp. 69-89. New York: Cambridge University Press.

BARber, J. AND ANDERSON, B. (1992). Too much of a good thing: Light can be bad for photosynthesis. Trends biol. Sci. 17, 61-66.

BERRY-Lowe, S. L. AND SCHMIDT, G. W. (1991). Chloroplast protein transport. In The Molecular Biology of Plastids: Cell Culture and Somatic Cell Genetics of Plants, vol. 7A (ed. L. Bogograd and I. K. Vasil), pp. 257-302. New York: Academic Press.

Bidwell, J. P. AND SPOTTE, S. (1985). Artificial Seawaters; Formulas and Methods. pp. 305-306. Boston: Jones and Bartlett Publishers, Inc.

Brennicke, A., Grohmann, L., Hiesel, R., Knoop, V. And Schuster, W. (1993). The mitochondrial genome on its way to the nucleus: Different stages of gene transfer in higher plants. FEBS Lett. 325, 140-145.

Christopher, D. A. AND Mullet, J. E. (1994). Separate photosensory pathways co-regulate blue light/ultraviolet-Aactivated $p s b \mathrm{D}-p s b \mathrm{C}$ transcription and light induced $\mathrm{D} 2$ and $\mathrm{CP} 43$ degradation in barley (Hordeum vulgare) chloroplasts. Plant Physiol. 104, 1119-1129.

Gamble, P. E. AND Mullet, J. E. (1989a). Translation and stability of proteins encoded by the plastid $p s b \mathrm{~A}$ and $p s b \mathrm{~B}$ genes are regulated by a nuclear gene during light-induced chloroplast development in barley. J. biol. Chem. 264, 7236-7243.

Gamble, P. E. And Mullet, J. E. (1989b). Blue light regulates the accumulation of two $p s b \mathrm{D}-p s b \mathrm{C}$ transcripts in barley chloroplasts. EMBO J. 8, 2785-2794.

GounARIS, K., BARBER, J. AND HARWOOD, J. L. (1986). The thylakoid membranes of higher plant chloroplasts. Biochem. J. 237, 313-326.

Grassi, C. AND MorandinI, G. C. (1976). A controlled trial of intermittent oral acetylcysteine in the long-term treatment of chronic bronchitis. Eur. J. clin. Pharmac. 9, 393-396.

Graves, D. A., Gibson, M. A. And Bleakney, J. S. (1979). The digestive diverticula of Alderia modesta and Elysia chlorotica. Veliger 21, 415-422.

Greenburg, B. M., Gaba, V., Cananni, O., Malkin, S., Mattoo, A. T. AND EdElman, M. (1989). Separate photosensitizers mediate degradation of the $32 \mathrm{kDa}$ photosystem II reaction center protein in 


\section{S. K. Pierce, R. W. Biron And M. E. RumPho}

the visible and UV spectral regions. Proc. natn. Acad. Sci. U.S.A. 86, 6617-6620.

GreENE, R. W. (1970). Symbiosis in sacoglossan opisthobranchs: translocation of photosynthetic products from chloroplast to host tissue. Malacologia 10, 357-368.

Grossman, A., Mandori, A. And Snyder, D. (1990). Lightharvesting proteins of diatoms: Their relationship to the chlorophyll $\mathrm{a} / \mathrm{b}$ binding proteins of higher plants and their mode of transport into plastids. Molec. gen. Genetics 224, 91-100.

Hinde, R. AND SMith, D. C. (1974). 'Chloroplast symbiosis' and the extent to which it occurs in Sacoglossa (Gastropoda: Mollusca). Biol. J. Linn. Soc. 6, 349-356.

KeEgStRA, K. (1989). Transport and routing of proteins into chloroplasts. Cell 56, 247-253.

KHAKHINA, L. (1992). Evolutionary significance of symbiosis: Development of the symbiogenesis concept. Symbiosis 14, 217-228.

KowALliK, K. V. (1989). Molecular aspects and phylogenetic implications of plastid genomes of certain chromophytes. In The Chromophytic Algae: Problems and Perspectives, vol. 38, pp. 101-124. Oxford: Clarendon Press.

Margulis, L. AND Bermudes, D. (1985). Symbiosis as a mechanism of evolution: Status of cell symbiosis theory. Symbiosis 1, 101-124.

Mattoo, A. K., Marder, J. B. and Edelman, M. (1989). Dynamics of the photosystem II reaction center. Cell 56, 241-246.

Mullet, J. E. (1993). Dynamic regulation of chloroplast transcription. Plant Physiol. 103, 309-313.

Muscatine, L., Pool, R. R. And Trench, R. K. (1975). Symbiosis of algae and invertebrates: Aspects of the symbiont surface and the host-symbiont interface. Trans. Am. microsc. Soc. 94, 450-469.

ORWITZ, W. (1990). Increased turnover of a polypeptide associated with the light-harvesting chlorophyll protein complex II in partially bleached Euglena gracilis. J. Plant Physiol. 136, 187-192.

OtT, D. W. AND BRown, R. M. (1974). Developmental cytology of the genus Vaucheria. I. Organization of the vegetative filament. $J$. Phycol. 9, 111-126.
Pardy, R. L., Lewin, R. A. AND LeE, K. (1983). The Prochloron symbiosis. In Algal Symbiosis: A Continuum of Interaction Strategies (ed. L. J. Goff), pp. 91-96. New York: Cambridge University Press.

REAS, H. W. (1963). The effect of N-acetylcysteine on the viscosity of tracheobronchial secretions of cystic fibrosis of the pancreas. $J$. Pediatr. 62, 31-35.

Rumpho, M. E. AND EDWARDS, G. E. (1984). Inhibition of 3-PGA dependent $\mathrm{O}_{2}$ evolution by PEP in $\mathrm{C}_{4}$ mesophyll chloroplasts of Digitania sanguinalis. Plant Physiol. 76, 711-718.

Schuster, G., Timberg, R. AND OHAD, I. (1988). Turnover of thylakoid photosystem II proteins during photoinhibition of Chlamydomonas reinhardtii. Eur. J. Biochem. 177, 403-410.

Soll, J. AND Alefsen, H. (1993). The protein import apparatus of chloroplasts. Physiol. Plant 87, 433-440.

TAYLOR, D. L. (1970). Chloroplasts as symbiotic organelles. Int. Rev. Cytol. 27, 29-64.

Trench, R. K. (1975). Of 'Leaves That Crawl': functional chloroplasts in animal cells. Soc. exp. Biol. Cambridge Symp. 29 , 229-266.

TRENCH, R. K. (1979). The cell biology of plant-animal symbiosis. A. Rev. Plant Physiol. 30, 485-453.

Trench, R. K., Boyle, J. E. AND Smith, D. C. (1973). The association between chloroplasts of Codium fragile and the mollusc, Elysia viridis. II. Chloroplast ultrastructure and photosynthetic carbon fixation in E. viridis. Proc. R. Soc. Lond. A 184, 51-61.

WalKer, D. A., Cerovic, Z. G. AND Robinson, S. P. (1987). Isolation of intact chloroplasts: general principles and criteria of integrity. In Methods in Enzymology - Plant Cell Membranes, vol. 148 (ed. L. Packer and R. Douce), pp. 195-206. New York: Academic Press.

WeSt, H. H. (1979). Chloroplast symbiosis and development of the ascoglossan opisthobranch Elysia chlorotica. $\mathrm{PhD}$ thesis, Northwestern University.

West, H. H., Harrigan, J. AND Pierce, S. K. (1984). Hybridization of two populations of a marine opisthobranch with different developmental patterns. Veliger 26, 199-206. 